\title{
The Effect of Heat Treatment on Dynamic Strain Aging Behaviour of AISI H10 Hot Work Tool Steel
}

\author{
Demet Taştemura, Süleyman Gündü̈ ${ }^{a}$ * \\ ${ }^{a}$ Department of Manufacturing Engineering, Technology Faculty, Karabük University, 78050, Karabük, \\ Turkey
}

Received: June 07, 2017; Revised: October 30, 2017; Accepted: November 10, 2017

\begin{abstract}
Dynamic strain aging (DSA) behaviour of hot work tool steel (H10) was investigated under asreceived (AR) and as-quenched (AQ) conditions. Hot tensile test was carried out in the temperatures of $25^{\circ} \mathrm{C}-700^{\circ} \mathrm{C}$ at a strain rate of $1 \times 10^{-3} \mathrm{~s}^{-1}$. The tensile properties indicated that AQ samples showed an increase in yield strength (YS) and ultimate tensile strength (UTS) but a decrease in elongation at $200^{\circ} \mathrm{C}$ or $300^{\circ} \mathrm{C}$ consistent with DSA. However, AR samples revealed a decrease in YS and UTS for the same testing temperatures. This indicated the presence of less amount of free $\mathrm{C}$ or $\mathrm{N}$ in solution of AR samples. Further increase in the testing temperature has increased the elongation. It is believed that DSA occurs in $\mathrm{H} 10$ tool steel at different temperatures because of interaction between dislocations and interstitial solute atoms $(\mathrm{C}$ or $\mathrm{N})$ or substitutional atoms $(\mathrm{Cr}$ or $\mathrm{Mo})$.
\end{abstract}

Keywords: Hot work tool steel, Dynamic strain aging, Mechanical properties

\section{Introduction}

The steels used for hot forming is a special type of tool steel, made to withstand a combination of heat, pressure and abrasion and has been classified hot work tool steel, AISI type H. All hot-work tool steels are used in a quenched and tempered condition. The most essential properties for these types of steels are high levels of hot strength, ductility, toughness, thermal conductivity, creep strength, temper resistance and also low thermal expansion ${ }^{1,2}$. Hot work tool steels have alloyed with carbide forming elements such as $\mathrm{Cr}, \mathrm{V}$ and Mo. These elements play an important role when the tool steels are subjected to high temperatures, since they precipitate as fine alloy carbides, which not only retards the softening but also increases the strength ${ }^{3}$. Hardenability of these steels is high and effected by the presence of different alloying elements. Forexample, if Mo is present in amounts of $1 \%$ or greater in the steel, hardenability is strongly effected. $\mathrm{W}$ contributes little to hardenability. However, $\mathrm{V}$ reduces hardenability by bonding $\mathrm{C}$ in the form of $\mathrm{VC}$. In order to obtain secondary hardening during tempering, austenitisation should be designed to put higher amount of alloy and $\mathrm{C}$ in solution as much as possible, while avoiding abnormal grain growth and excessive retained austenite. These informations are important in designing hot work schedules and heat treatments for annealing and hardening ${ }^{4,5}$.

Hot work tool steels microstructures consist of tempered martensite with high dislocation density and precipitates of carbide. These steels with high alloy content and dislocation density can indicate that DSA may occur in hot work tool steel. The elastic interaction between dislocations and interstitial atoms/precipitates in the steel causes the dislocations to

*e-mail: sgunduz@karabuk.edu.tr be firmly pinned which can lead to occurrence of strain aging (SA) .

Strain aging is classified as static strain aging (SSA) which occurs after plastic deformation of the aging process, and DSA which occurs during plastic deformation. The SSA leads to the reappearance of the upper yield point and the yield point elongation, while the DSA has been shown to result in the inhomogeneous deformation characterized by serrated flow. However, in both cases flow stress and workhardening rate show an increase while a decrease in ductility is observed ${ }^{7}$. DSA may induce negative strain rate sensitivity and may even cause flow limitation in cold and warm areas during plastic deformation. For this reason, effect of the DSA on deformation pattern and mechanical properties are important for the correct design of the metal forming process $^{8}$. Several researches have been conducted to study the effect of DSA on mechanical properties in various engineering alloys.

Literature survey indicated that there are considerable information relating to the effect of carbide forming elements on high temperatures mechanical properties of hot work tool steels. However, it was observed that no extensive investigation was done into DSA in hot work tool steel. Therefore, the occurrence of DSA and its effects on microstructure and strength of $\mathrm{H} 10$ hot work tool steel are investigated under $\mathrm{AR}$ and $\mathrm{AQ}$ conditions in the present study.

\section{Experimental Procedure}

AISI H10 type hot work tool steel was chosen to study DSA behaviour in AR and AQ conditions. Table 1 shows the chemical composition of steel. In order to prevent 
Table 1. Chemical composition of steel used in research

\begin{tabular}{ccccccccc}
\hline Elements & $\mathrm{C}$ & $\mathrm{Si}$ & $\mathrm{Mn}$ & $\mathrm{P}$ & $\mathrm{S}$ & $\mathrm{Cr}$ & $\mathrm{Mo}$ & $\mathrm{V}$ \\
\hline $\mathbf{W t} \%$ & 0.31 & 0.25 & 0.30 & 0.017 & $<0.001$ & 3.19 & 2.73 & 0.5 \\
\hline
\end{tabular}

precipitations of carbonitrides and increase the amount of $\mathrm{C}$ and $\mathrm{N}$ in solid solution AQ samples were austenitised at $1050^{\circ} \mathrm{C}$ for $1 \mathrm{~h}$. and then cooled in water. Austenization temperature of $1050^{\circ} \mathrm{C}$ and time of $1 \mathrm{~h}$. were selected to put higher amount of alloy and $\mathrm{C}$ in solution which may affect the DSA behaviour of investigated steel. Tensile test specimens for DSA were manufactured with $30 \mathrm{~mm}$ gage length and $5 \mathrm{~mm}$ diameter as shown in Fig. 1. Tensile tests were done using a MTS $(100 \mathrm{kN}$ Servohydraulic Dynamic Tester) at a strain rate of $1 \times 10^{-3} \mathrm{~s}^{-1}$ for the temperatures of $25^{\circ} \mathrm{C}$ to $700^{\circ} \mathrm{C}$. After each test, stress and strain diagrams were obtained. Values of YS (0.2\%), UTS, elongation (\%) and workhardening rate $(\delta y)$ were determined.

In the present work, optical microscopy and scanning electron microscopy (SEM) equipped by EDS have been used to characterise steel microstructure, precipitate particles and fracture surfaces for the samples tested in the temperature range of $25^{\circ} \mathrm{C}-700^{\circ} \mathrm{C}$. In preparing a specimen for microscopical examination it was first necessary to produce flat and scratch free surface when viewed with a microscope. The samples were wet ground by using coarse, intermediate and finer grinding on a series of silicon carbide papers to 1200 mesh and then polished to a 1 micron finish using a diamond abrasive compound in order to remove the marks left by grinding. All prepared samples were etched in Nital solutioun to reveal the microstructure.

\section{Results and Discussion}

Fig. 2 reveals the SEM micrographs for the AR samples tested at $25^{\circ} \mathrm{C}, 200^{\circ} \mathrm{C}, 400^{\circ} \mathrm{C}$ and $700^{\circ} \mathrm{C}$. As can be seen, the steel consistent of ferrite structure with alloy carbides which were distributed along the grain boundaries after testing at room temperature (Fig 2a). It was observed that carbides are distributed more homogenously when the testing temperature is increased to $200^{\circ} \mathrm{C}, 400^{\circ} \mathrm{C}$ or $700^{\circ} \mathrm{C}$ (Figs. $2 \mathrm{~b}, 2 \mathrm{c}$ and $2 \mathrm{~d})$. These carbides have an important role in increasing high temperature resistance of steels ${ }^{4}$. Tool steel

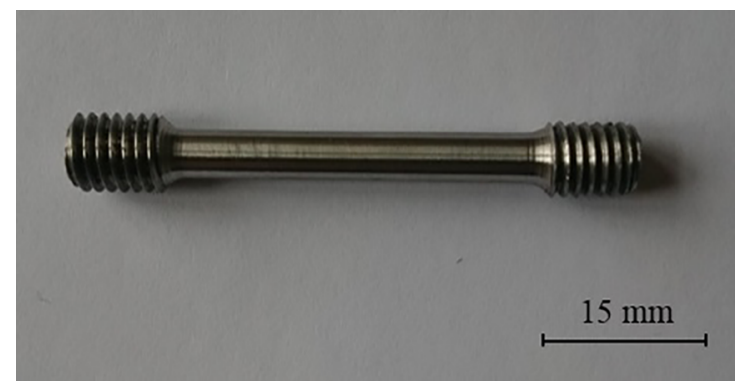

Figure 1. Tensile test specimen used for hot tensile testing. are usally delivered to the user as soft annealed condition. In the soft annealed condition, the carbides are embedded in the matrix. Coarser carbides with angular shape and finer carbides with spheroid shape existed through the ferrite matrix. Fig. 2 also shows EDS analysis with the spectrum points 1-5 marked on the microstructure of AR samples tested at $400^{\circ} \mathrm{C}$. Points $1-3$ contains $\mathrm{Mo}$ and $\mathrm{C}$, point 4 contains $\mathrm{Cr}$ and $\mathrm{C}$. The presence of these elements indicates that $\mathrm{M}_{6} \mathrm{C}\left(\mathrm{Mo}_{6} \mathrm{C}\right)$ and $\mathrm{M}_{23} \mathrm{C}_{6}\left(\mathrm{Cr}_{23} \mathrm{C}_{6}\right)$ occurred in $\mathrm{H} 10$ tool steel under $\mathrm{AR}$ condition and contributed to high temperature resistance between $200-400^{\circ} \mathrm{C}$ as suggested by Bahrami et al. ${ }^{9}$. Such carbides forming elements may also interfere with the interstitial atoms and cause dynamic strain aging.

Fig. 3 reveals the microstructure of AQ samples austenitised at $1050^{\circ} \mathrm{C}$ and then cooled in water. The SEM micrograph shows martensite phase with small amount spheroid carbide particles which are distributed through the matrix. These martensite phase is uniform and exhibited minimal signs of alloy segregations due to higher cooling rates. This indicated that higher amount of carbon stayed in solid solution of the AQ samples. Cooling in water does not allow the precipitation of all carbides which indicates the presence of $\mathrm{C}$ in solid solution, which affects the mechanical properties of steel ${ }^{10}$. Fig. 3 also reveals EDS analysis with the specturum points 1, 2, 3 and 4 marked on the microstructure of samples tested at $400^{\circ} \mathrm{C}$. Point 1 contains $\mathrm{Fe}, \mathrm{C}, \mathrm{Mo}$, point 2 contains $\mathrm{Fe}$, $\mathrm{C}, \mathrm{V}$ but points 3 and 4 contain $\mathrm{Fe}$ and $\mathrm{C}$. The presence of these elements indicated that small amount spheroid MoC, VC and FeC occurred in AQ samples tested at $400^{\circ} \mathrm{C}$.

Tables 2 and 3 show hot tensile test results for $\mathrm{H} 10$ tool steel under AR and AQ conditions, including UTS, YS and elongation (\%). It is noted that UTS and YS are about 646 $\mathrm{MPa}$ and $451 \mathrm{MPa}$ for AR samples and $2084 \mathrm{MPa}$ and 1676 $\mathrm{MPa}$ for AQ samples respectively. Increasing test temperature within the range of $100^{\circ} \mathrm{C}-400^{\circ} \mathrm{C}$ causes decrease in UTS and YS to $522 \mathrm{MPa}$ and $408 \mathrm{MPa}$ for $\mathrm{AR}$ and $1687 \mathrm{MPa}$ and $1335 \mathrm{MPa}$ for AQ samples respectively. Exceeding testing temperature of $400^{\circ} \mathrm{C}$ causes a significand decline. It was also observed that as the testing temperature increased to $400^{\circ} \mathrm{C}$ a continuous decrease in elongation was noticed. Further increase in the testing temperature of 500, 600 or $700^{\circ} \mathrm{C}$ has increased the elongation. It can be concluded that above $400^{\circ} \mathrm{C}$ mechanical properties of $\mathrm{H} 10$ steel become so poor under $\mathrm{AR}$ and $\mathrm{AQ}$ conditions. The results obtained from this study is consistent with the results obtained from Gündüz and Cochrane ${ }^{11}$ who investigated the effect of temperature on the UTS of vanadium microalloyed steels under as-received, stainless steel cooled and air cooled conditions. They observed rapid decrease in strength from room temperature to $100^{\circ} \mathrm{C}$ 

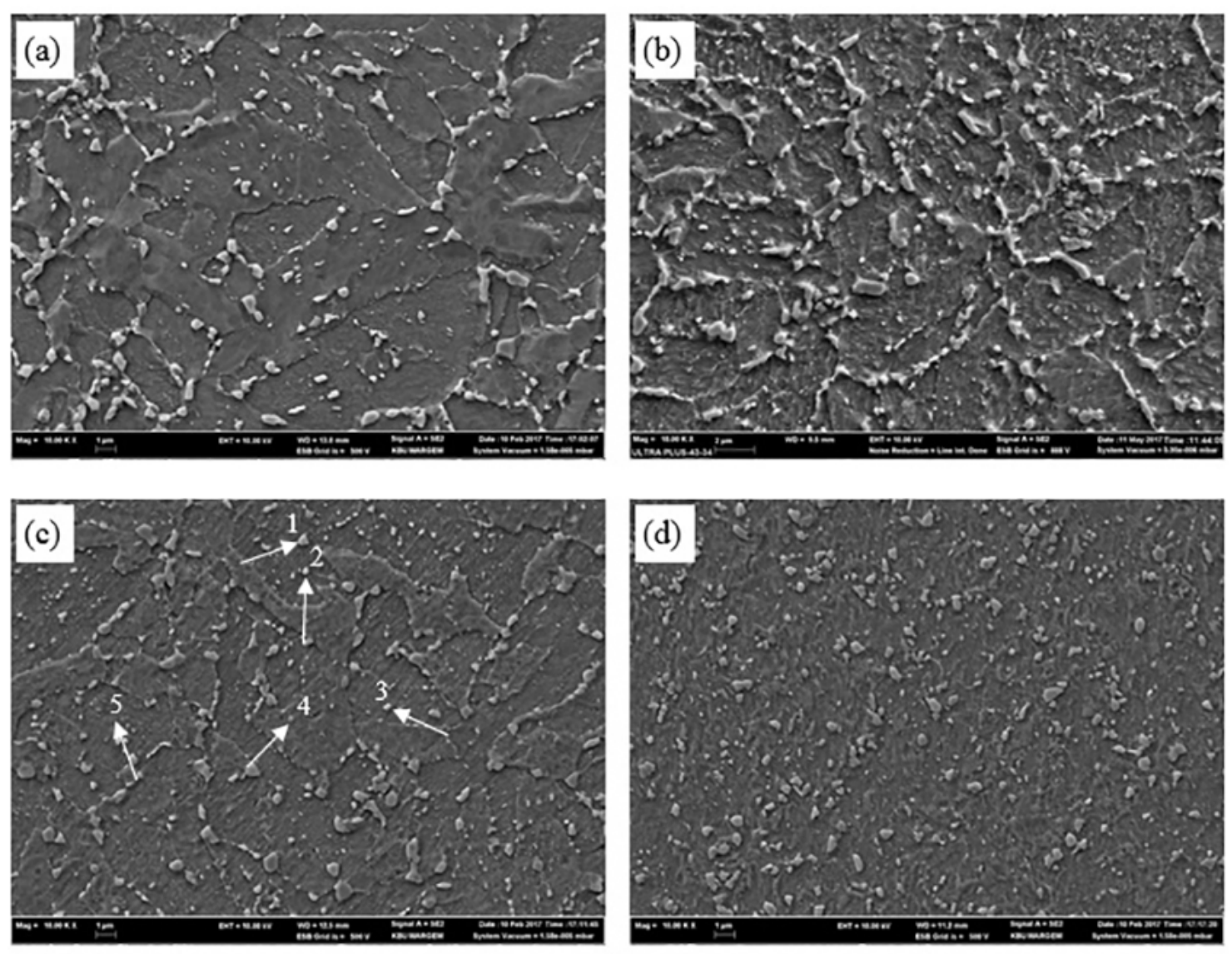

Mass percent $(\%)$

(e)

\begin{tabular}{|c|c|c|c|c|c|c|c|c|}
\hline Spectrum & C & $\mathrm{N}$ & Si & V & $\mathrm{Cr}$ & $\mathrm{Mn}$ & $\mathrm{Fe}$ & Mo \\
\hline 1 & & 40 & 1.27 & 9 & 2.81 & 1.04 & 62.83 & 22. \\
\hline 2 & & & & & & 0 . & & \\
\hline 3 & & 1.6 & 1. & & 4. & 0.43 & & 33. \\
\hline 4 & & 1.03 & 0.12 & 1.31 & 13. & 0.00 & 76. & 0.75 \\
\hline 5 & 2.80 & 0.73 & 0.31 & 0.41 & 1.44 & 1.19 & 92.46 & 0.66 \\
\hline & & & & & & & & \\
\hline & 2.4 & 0.40 & 0.84 & & 4. & 0 . & 19. & 17.1 \\
\hline Sigma & 1.0 & 0.18 & 0.38 & 0.21 & 2.13 & 0.22 & 8.74 & 76 \\
\hline
\end{tabular}

Figure 2. Microstructure of the as-received samples tested at (a) $25^{\circ} \mathrm{C}$, (b) $200^{\circ} \mathrm{C}$, (c) $400^{\circ} \mathrm{C}$ (d) $700^{\circ} \mathrm{C}$ and (e) correspondig EDS of the indicated particles in samples tested at $400^{\circ} \mathrm{C}$.

then slower decrease corresponding to DSA which persists up to $200-400^{\circ} \mathrm{C}$ because of the interaction between solute atoms/precipitate particles and dislocations.

The results also indicated that AQ samples are more susceptible to DSA than AR samples. For example, AQ samples showed higher values in YS and UTS but lower values in elongation (\%) compared to the AR samples for all testing temperatures of $25-700^{\circ} \mathrm{C}$. The changes in mechanical properties due to DSA in steel of the present investigation are similar to that of plain carbon steel and alloy steel. It was shown that higher dislocation density was observed in DSA range compared to that at room temperature. The major contributions to the higher YS or UTS come from the increased workhardening ${ }^{12}$. In DSA, the diffusion of the interstitial atoms to dislocations occurs simultaneously with straining. Accordingly, the temperature range of DSA is above that of SSA because rapid diffusion of nitrogen and carbon is required and this is aided by raising the temperature. The result of the interaction between interstitial atoms and dislocations includes increased tensile strength, 

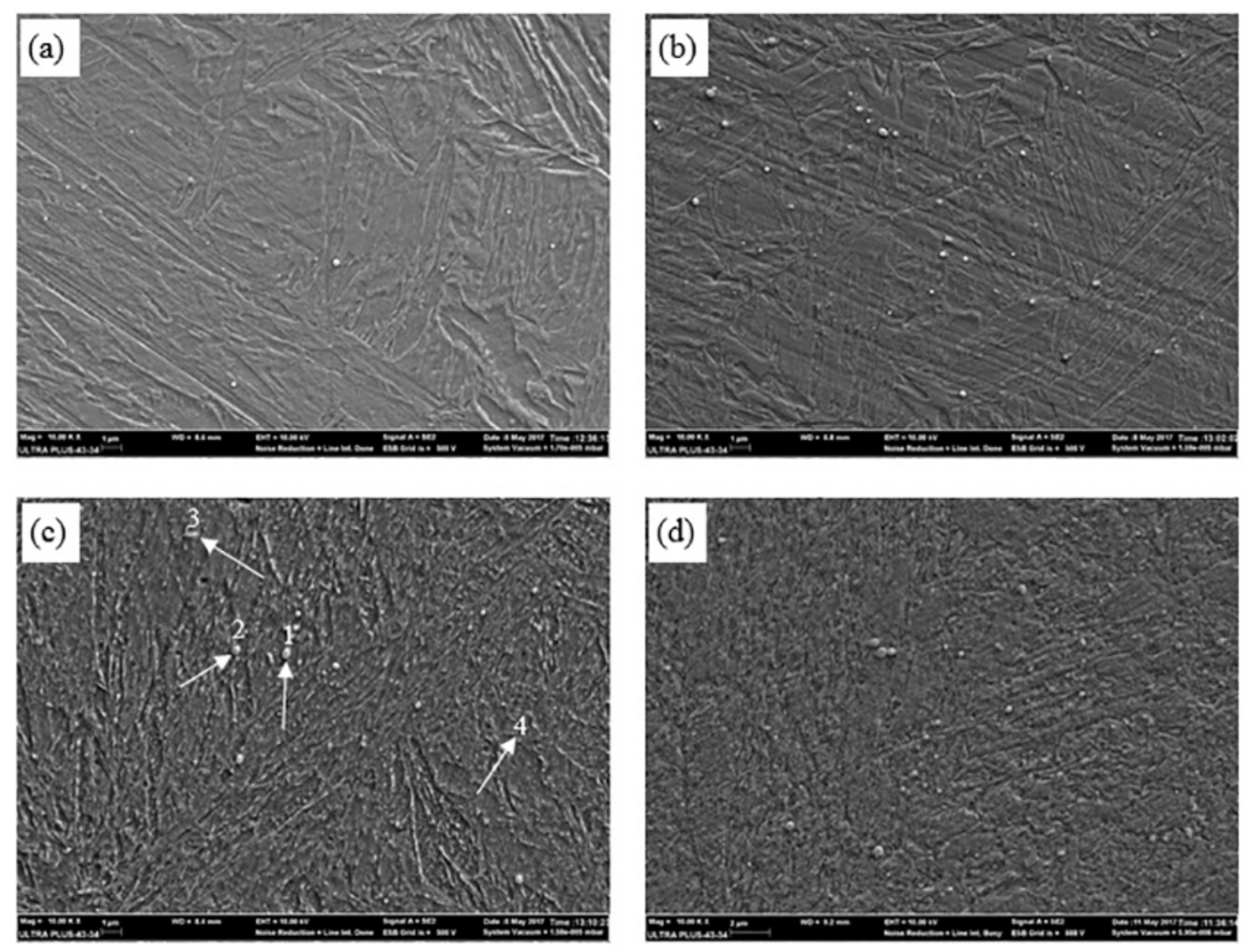

\begin{tabular}{|c|c|c|c|c|c|c|c|c|c|}
\hline Spectrum & C & Si & P & S & V & $\mathrm{Cr}$ & $\mathrm{Mn}$ & $\mathrm{Fe}$ & Mo \\
\hline $\begin{array}{l}1 \\
2 \\
3 \\
4\end{array}$ & $\begin{array}{r}6.81 \\
6.36 \\
28.76 \\
2.78\end{array}$ & $\begin{array}{l}1.08 \\
0.05 \\
0.28 \\
0.30\end{array}$ & $\begin{array}{l}0.00 \\
0.00 \\
0.00 \\
0.00\end{array}$ & $\begin{array}{l}0.24 \\
0.04 \\
0.35 \\
0.09\end{array}$ & $\begin{array}{l}2.76 \\
6.32 \\
0.62 \\
0.51\end{array}$ & $\begin{array}{l}3.33 \\
2.33 \\
2.81 \\
3.17\end{array}$ & $\begin{array}{l}0.28 \\
0.32 \\
0.22 \\
0.01\end{array}$ & $\begin{array}{l}50.11 \\
82.17 \\
65.57 \\
90.95\end{array}$ & $\begin{array}{r}35.38 \\
2.42 \\
1.39 \\
2.19\end{array}$ \\
\hline $\begin{array}{l}\text { Mean value: } \\
\text { Sigma: } \\
\text { Sigma mean: }\end{array}$ & $\begin{array}{r}11.18 \\
11.86 \\
5.93\end{array}$ & $\begin{array}{l}0.43 \\
0.45 \\
0.23\end{array}$ & $\begin{array}{l}0.00 \\
0.00 \\
0.00\end{array}$ & $\begin{array}{l}0.18 \\
0.14 \\
0.07\end{array}$ & $\begin{array}{l}2.55 \\
2.72 \\
1.36\end{array}$ & $\begin{array}{l}2.91 \\
0.45 \\
0.22\end{array}$ & $\begin{array}{l}0.21 \\
0.14 \\
0.07\end{array}$ & $\begin{array}{r}72.20 \\
18.10 \\
9.05\end{array}$ & $\begin{array}{r}10.35 \\
16.70 \\
8.35\end{array}$ \\
\hline
\end{tabular}

Figure 3. Microstructure of the as-quenched samples tested at (a) $25^{\circ} \mathrm{C}$, (b) $200^{\circ} \mathrm{C}$, (c) $400^{\circ} \mathrm{C}$ (d) $700^{\circ} \mathrm{C}$ and (e) correspondig EDS of the indicated particles in samples tested at $400^{\circ} \mathrm{C}$.

decreased ductility, increased workhardening rate, and the occurence of serrations on the stress-strain curve. The increased workhardening rate and increased tensile strength are believed to arise from greater than normal dislocation densities in steels that exhibit DSA. These high dislocation densities are believed to occur because of the pinning, which requires that fresh dislocations be formed continually to maintain the applied strain rate ${ }^{13}$.

Fig. 4a shows YS $(0.2 \%)$ values at different testing temperatures for AR and AQ samples. As can be seen, the YS continuously decreased with rising in testing temperature for AR samples and the rate of fall was lower from $200^{\circ} \mathrm{C}$ to $400^{\circ} \mathrm{C}$. There was a mild peak at $400^{\circ} \mathrm{C}$ at the strain rate of $1 \times 10^{-3} \mathrm{~s}^{-1}$. On the other hand, an increase in YS was observed with rising the testing temperature from 25 to $200^{\circ} \mathrm{C}$ for $\mathrm{AQ}$ samples and then it continuously decreased with further increase in testing temperature for the strain rate of $1 \times 10^{-3} \mathrm{~s}^{-1}$. Martensite occured in steel is not stable at room temperature because $\mathrm{C}$ atoms can diffuse in the martensite lattice at these temperatures. This instability increases between room temperature and $250^{\circ} \mathrm{C}$, when $\varepsilon$-carbide precipitates in the martensite. It was indicated that carbide forming elements 
Table 2. Tensile properties of as-received samples at various temperatures

\begin{tabular}{cccc}
\hline $\begin{array}{c}\text { Test } \\
\text { Temperatures } \\
\left({ }^{\circ} \mathbf{C}\right)\end{array}$ & $\begin{array}{c}\text { Ultimate } \\
\text { Tensile } \\
\text { Strenght } \\
(\mathbf{M P a})\end{array}$ & $\begin{array}{c}\text { Yield } \\
\text { Strenght }(\mathbf{0 . 2} \\
\mathbf{\% M P a})\end{array}$ & $\begin{array}{c}\text { Elongation } \\
(\mathbf{\%})\end{array}$ \\
\hline RT & 646 & 451 & 24 \\
100 & 569 & 426 & 22 \\
200 & 548 & 397 & 20 \\
300 & 525 & 388 & 20 \\
400 & 522 & 408 & 17 \\
500 & 468 & 363 & 24 \\
600 & 319 & 239 & 44 \\
700 & 195 & 132 & 58 \\
\hline
\end{tabular}

Table 3. Tensile properties of as-quenched samples at various temperatures

\begin{tabular}{cccc}
\hline $\begin{array}{c}\text { Test } \\
\text { Temperatures } \\
\left({ }^{\circ} \mathbf{C}\right)\end{array}$ & $\begin{array}{c}\text { Ultimate } \\
\text { Tensile } \\
\text { Strenght } \\
\text { (MPa) }\end{array}$ & $\begin{array}{c}\text { Yield } \\
\text { Strenght }(\mathbf{0 . 2} \\
\text { \%MPa) }\end{array}$ & $\begin{array}{c}\text { Elongation } \\
(\%)\end{array}$ \\
\hline RT & 2084 & 1676 & 8 \\
100 & 2094 & 1679 & 7 \\
200 & 2130 & 1701 & 9 \\
300 & 1847 & 1454 & 7 \\
400 & 1687 & 1335 & 12 \\
500 & 1488 & 1246 & 14 \\
600 & 1289 & 1179 & 13 \\
700 & 609 & 561 & 21 \\
\hline
\end{tabular}

such as $\mathrm{Cr}, \mathrm{Mo}, \mathrm{V}, \mathrm{W}$ and $\mathrm{Ti}$ are present in a steel in sufficient concentration their carbides can be formed in preference to cementite. However, during the heating of steels, carbides don't form until the temperature of $500-600^{\circ} \mathrm{C}$, because below this, the elements cannot diffuse rapidly to allow the nucleation of carbides. Consequently, higher temperatures are necessary for the diffusion of the elements before nucleation and growth of the carbides ${ }^{14}$. An increase in strength of $\mathrm{AQ}$ samples at testing temperatures of $25-200^{\circ} \mathrm{C}$ is due to precipitation hardening of martensite by $\varepsilon$-carbide. Further increase in testing temperature decreased the strength of AQ samples due to lack of the precipitation of alloy carbides. The strength of tool steels is mainly affected by precipitation hardening and, to small extent, solid solution hardening ${ }^{15}$.

The effect of testing temperature on UTS is also presented in Fig. $4 \mathrm{~b}$ for AR and AQ samples. UTS continuously decreased with increasing in testing temperature for $\mathrm{AR}$ samples from $25^{\circ} \mathrm{C}$ to $400^{\circ} \mathrm{C}$ at the strain rate of $1 \times 10^{-3} \mathrm{~S}^{-1}$. There was flattening of the plot in the temperature of $200^{\circ} \mathrm{C}$ to $400^{\circ} \mathrm{C}$ at the strain rate of $1 \times 10^{-3} \mathrm{~s}^{-1}$. However, AQ samples showed an increase in UTS at the temperature of $25-200^{\circ} \mathrm{C}$. Further increase in testing temperatures continuously decreased UTS. The variation of percentage elongation with temperature is shown in Fig. 4c. As
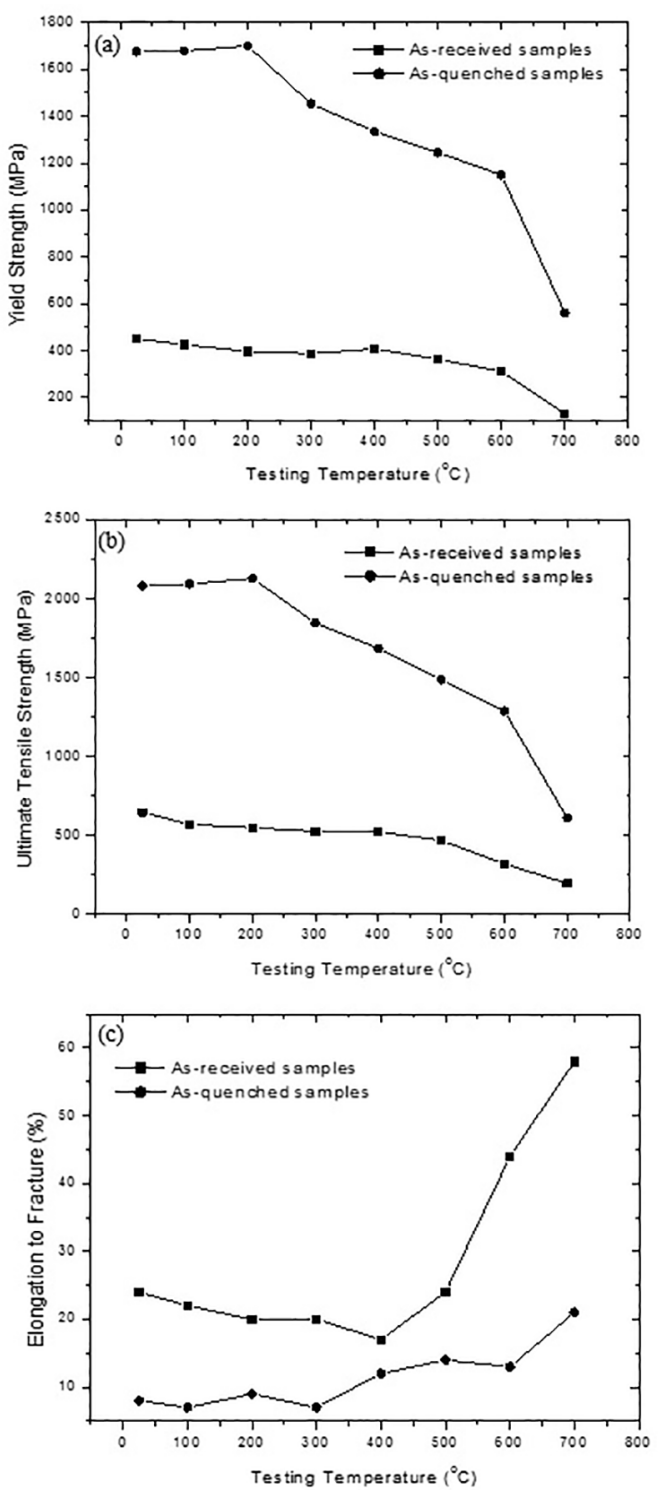

Figure 4. Variation of strength and elongation at different testing temperature: (a) yield strength (b) ultimate tensile strength and (c) percentage elongation.

is seen, elongation of AQ samples showed a decrease in the DSA temperature range $\left(200-400^{\circ} \mathrm{C}\right)$. This means that the effect of DSA is dominant at this temperature range. Gupta et al. ${ }^{16}$ have shown in their study on elevated temperature tensile properties of a $3 \mathrm{Cr}$-1Mo steel, that the UTS of specimens increases with increasing temperature, reach maximum at about $350^{\circ} \mathrm{C}$ and then decrease with further increase in temperature. Correspondingly, the ductility decreases with increasing temperature, reaching minimum values at around $350-400^{\circ} \mathrm{C}$, and then increases with increase in test temperatures. Similar results were also obtained by Keller et al. ${ }^{17}$ who characterized the critical strain rate and temperature conditions for DSA in tension for a modified T91 martensitic steel. DSA appears for temperatures ranging between 150 and $450^{\circ} \mathrm{C}$ and all strain rates. 
The tensile properties indicated that AQ samples showed an increase in YS and UTS but a decrease in elongation at $200^{\circ} \mathrm{C}$ or $300^{\circ} \mathrm{C}$ consistent with DSA. However, AR samples revealed a decrease in YS and UTS for the same testing temperatures. This indicated the presence of less amount of free $\mathrm{C}$ or $\mathrm{N}$ in solid solution of AR samples. This is consistent with the SEM results which indicated that AR samples contain more alloy carbides in ferrite structure. It was shown that strength decreased from room temperature to $100^{\circ} \mathrm{C}$, and then a slower decrease was occured corresponding to DSA from carbon which persists up to about $275-300^{\circ} \mathrm{C}$. Thereafter, small or negligible changes in flow stress are observed ${ }^{18,19}$.

Stress and strain diagrams of AR and AQ samples tested between $25-700^{\circ} \mathrm{C}$ at a strain rate of $1 \times 10^{-3} \mathrm{~S}^{-1}$ are shown in Figs. 5 and 6. Serrated flow, one of the characteristics of DSA, was not observed in AR and AQ samples. The serrated flow occurs when the solute atoms move to the dislocations and prevent their motion ${ }^{20-22}$. It is now well accepted that serrated yielding exhibited by a material occurs due to interaction between diffusing solute atoms and dislocations ${ }^{23}$. Serrated yielding was usually taken as the criterion for the occurrence of DSA. However, in some situations, DSA occurs without serrated yielding ${ }^{24}$ and several researchers have looked at this DSA which takes place outside the serrated flow regime ${ }^{25,26}$. Also, quantitative evaluation of strain aging tendency of materials is difficult by means of serrated yielding tests. This is very important when a number of material are to be compared. Kishore et al. ${ }^{27}$ have studied the occurrence of serrated stress-strain curves as a function of temperature

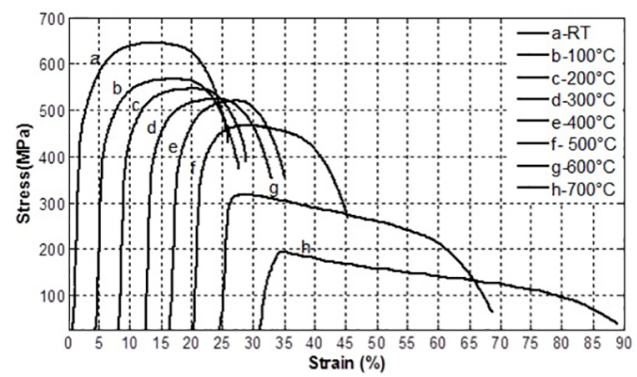

Figure 5. Tensile stress-strain curves of the as-received samples tested at different temperatures.

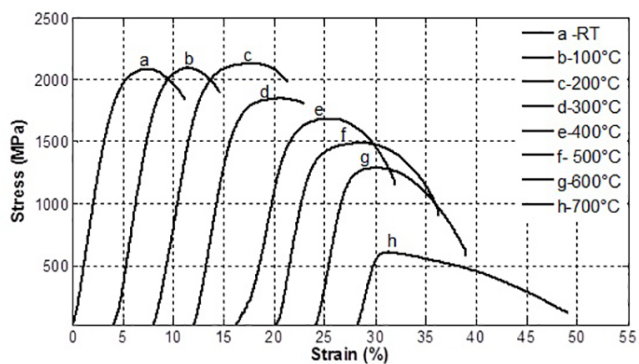

Figure 6. Tensile stress-strain curves of the as-quenched samples tested at different temperatures. and strain rate in $9 \mathrm{Cr} 1 \mathrm{Mo}$ steel susceptible to DSA. Their results indicated that, at a given temperature, the presence or absence of serrations is governed by strain rate.

In the present study, the workhardening rate $(\delta y)$ of the AR and AQ samples were determined to examine whether DSA takes place or not, because generally an increased workhardening rate $(\delta y)$ is a manifestation of DSA. The increase in flow stress because of DSA was taken as workhardening rate $(\delta y)$, which is difference between UTS and YS $(0.2 \%)$ as shown in Figure 7 . As can be seen from Fig 7 that workhardening rate $(\delta y)$ in AQ samples raised rapidly with increasing temperature, reaching a peak around $200^{\circ} \mathrm{C}$, and then decreased with further increase in test temperatures. However, the work hardening rate of AR samples showed a decrease compared to those in the room temperature testing conditions. The results obtained from present work showed that the increase in the workhardening magnitude in AQ samples is quite large compared to that at room temperature. However, workhardening magnitude of AR samples showed a decrease relative to that at room temperature. This indicated that the degree of DSA in AR samples containing coarser carbides with angular shape and finer carbides with spheroid shape is much smaller than AQ samples.

Fig. 8 shows SEM fractographs of the AR samples tested at $25^{\circ} \mathrm{C}, 200^{\circ} \mathrm{C}, 400^{\circ} \mathrm{C}$ and $700^{\circ} \mathrm{C}$. It was observed that samples tested at room temperature showed ductile dimple fracture mode with well defined microvoid morphology, which is associated with the nucleation, growth and coalescence of microcavities (Fig. 8a) ${ }^{28}$. On the other hand, a mixed pattern of dimple and cleavage facets is apparent in the sample tested at $200^{\circ} \mathrm{C}$ (Fig. 8 b) and $400^{\circ} \mathrm{C}$ (Fig. 8c). This is consistent with the elongation results which showed the lowest value after testing at $200^{\circ} \mathrm{C}$ and $400^{\circ} \mathrm{C}$. This is because of the interaction between solute atoms/precipitate particles and mobile dislocations ${ }^{29}$. Mukherjee and Sellars ${ }^{30}$ investigated DSA behaviour of Fe-Cr-C steels with tempered martensite

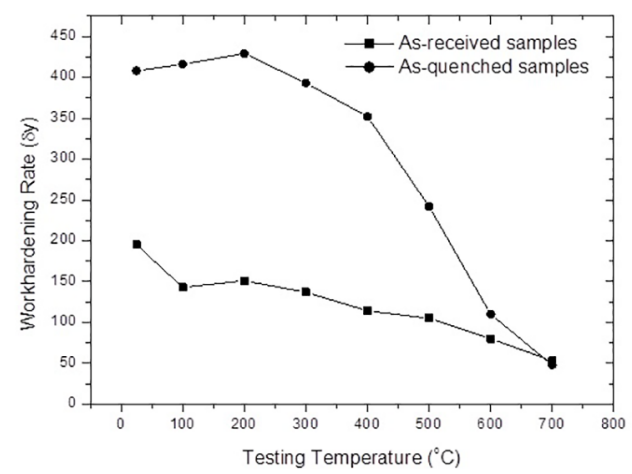

Figure 7. Workhardening rates $(\delta y)$ for as-received and as-quenched samples. 

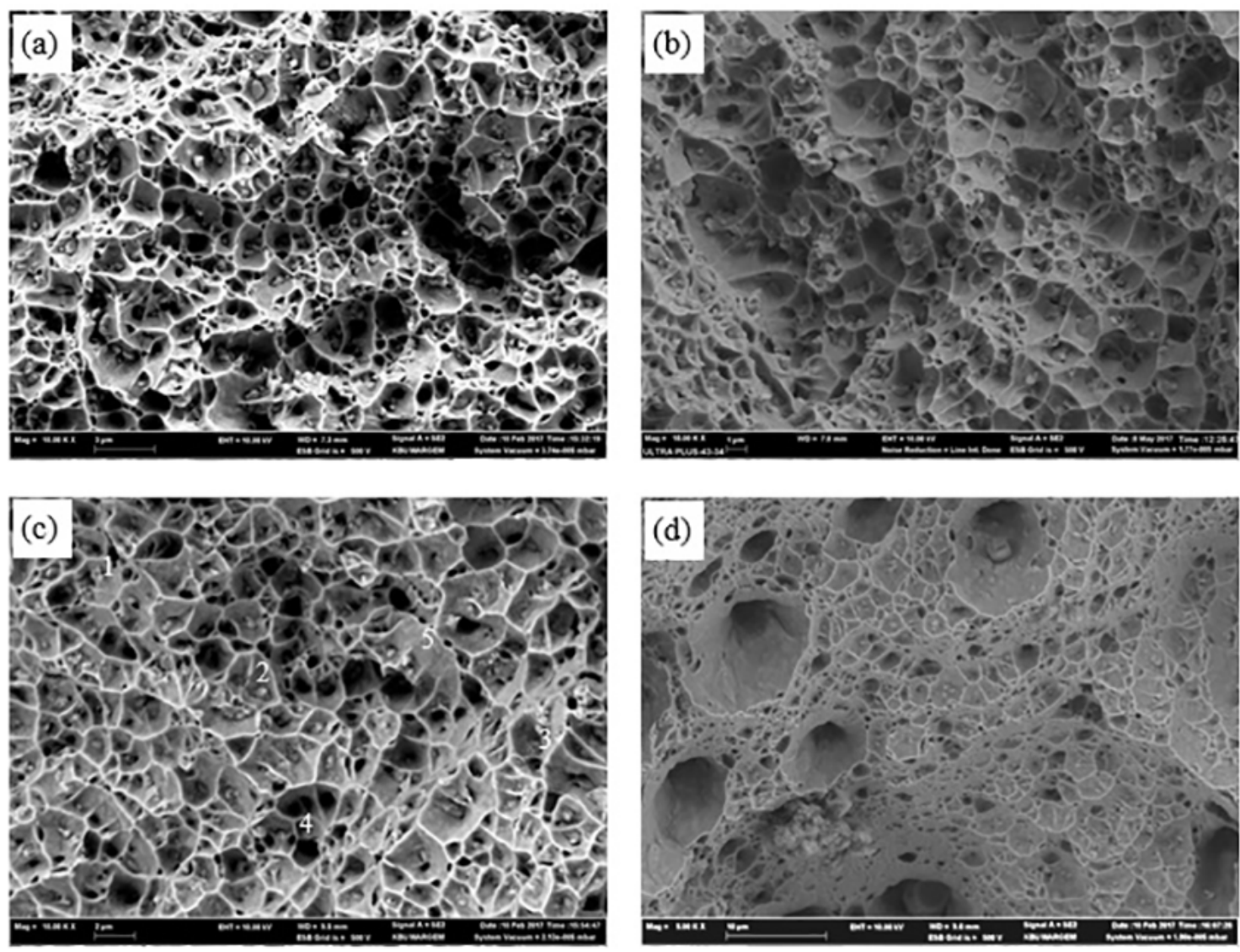

Mass percent ( $\%$ )

(e)

\begin{tabular}{|c|c|c|c|c|c|c|c|c|c|}
\hline Spectrum & C & $\mathrm{N}$ & 0 & $\mathrm{Si}$ & V & $\mathrm{Cr}$ & Mn & $\mathrm{Fe}$ & Mc \\
\hline 1 & 0.21 & 0.00 & 2.07 & 0.00 & 2.20 & 19.75 & 3.45 & 71.76 & 0 . \\
\hline 2 & 0.27 & 0.00 & 0.86 & 0.05 & 3.76 & 9.11 & 7.30 & 78.46 & 0. \\
\hline 3 & 2.39 & 0.15 & 8.36 & 1.14 & 1.65 & 5.31 & 1.67 & 47.96 & 31. \\
\hline 4 & 0.24 & 0.00 & 0.70 & 0.06 & 3.48 & 7.24 & 4.97 & 77.34 & 5. \\
\hline 5 & 3.22 & 0.13 & 7.06 & 0.08 & 0.10 & 2.59 & 1.50 & 84.78 & 0 . \\
\hline & 1.27 & & & & 24 & & 3.78 & 72.06 & \\
\hline Sigma: & 1.44 & 0.08 & 3.63 & 0.49 & 1.48 & 6.58 & 2.42 & 14.25 & 13. \\
\hline Sigma mean: & 0.64 & 0.03 & 1.62 & 0.22 & 0.66 & 2.94 & 1.08 & 6.37 & \\
\hline
\end{tabular}

Figure 8. Fracture surfaces of as-received samples tested at (a) $\mathrm{X} 25^{\circ} \mathrm{C}$, (b) $\mathrm{X} 200^{\circ} \mathrm{C}$, (c) $\mathrm{X} 400^{\circ} \mathrm{C}$, (d) $\mathrm{X} 700^{\circ} \mathrm{C}$ and (e) correspondig EDS of the indicated particles in samples tested at $400^{\circ} \mathrm{C}$.

in the $\mathrm{Cr}$ content of $0.87 \%-11.7 \%$. They observed that DSA occurred as a result of formation of $\mathrm{Cr}-\mathrm{C}$ complexes, which prevented dislocation movement up to $400^{\circ} \mathrm{C}$. At $700^{\circ} \mathrm{C}$, dimple pattern was observed again on the fracture surface with increasing elongation (Fig. 8d). Sample tested at $700^{\circ} \mathrm{C}$ also showed some deep large cusps which may be attributed to removal of precipitate particles through pulling of under heavy tensile loading conditions.
Fig. 9 also reveals the fracture surface of $A Q$ samples tested at $25^{\circ} \mathrm{C}, 200^{\circ} \mathrm{C}, 400^{\circ} \mathrm{C}$ and $700^{\circ} \mathrm{C}$. AQ samples tested at $25^{\circ} \mathrm{C}, 200^{\circ} \mathrm{C}$ or $400^{\circ} \mathrm{C}$ revealed mixed type fracture of cleavage facets and dimples (Figs. 9a, 9b and 9c). This is consistent with the results obtained by Verma et al. ${ }^{31}$ who observed quasi-cleavage fracture and river patterns at room temperature in modified $9 \mathrm{Cr}-1 \mathrm{Mo}$ steel. Clough and Soloman $^{32}$ also observed this type of fracture in $0.31 \mathrm{wt} \% \mathrm{C}$ 

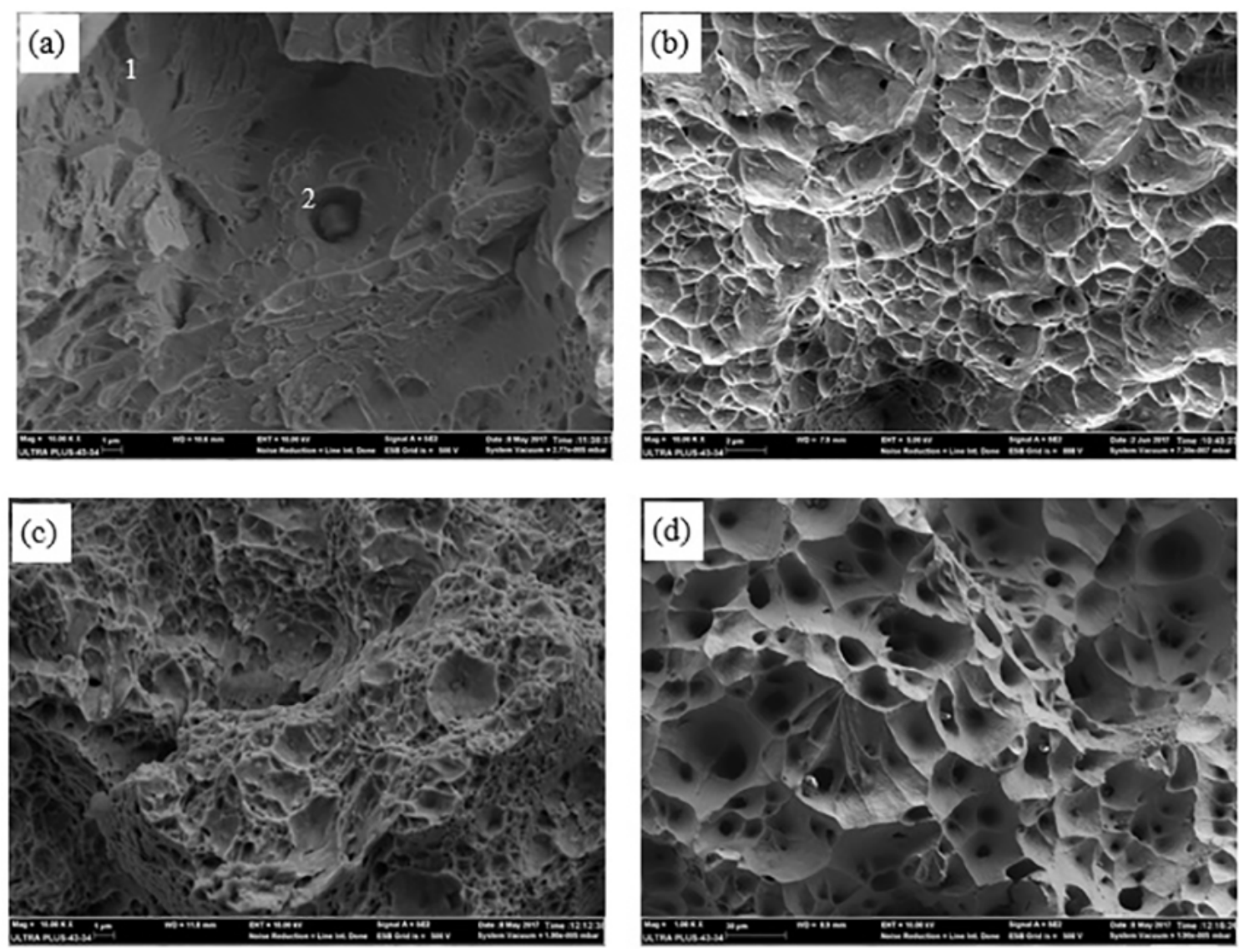

Mass percent $\left(\frac{\%}{)}\right.$

(e)

\begin{tabular}{|c|c|c|c|c|c|c|c|c|c|}
\hline Spectrum & C & $\mathrm{Si}$ & $\mathrm{P}$ & $\mathrm{S}$ & V & $\mathrm{Cr}$ & $\mathrm{Mn}$ & $\mathrm{Fe}$ & Mo \\
\hline 1 & 0.13 & 0.02 & 0.00 & 0.00 & 1.52 & 3.81 & 3.02 & 91.42 & 0.08 \\
\hline 2 & 14.69 & 0.72 & 0.00 & 0.00 & 0.00 & 22.33 & 0.00 & 62.26 & 0.00 \\
\hline Mean value: & 7.41 & 0.37 & 0.00 & 0.00 & 0.76 & 13.07 & 1.51 & 76.84 & 0. \\
\hline Sigma: & 10.30 & 0.50 & 0.00 & 0.00 & 1.08 & 13.10 & 2.13 & 20.62 & 0.06 \\
\hline Sigma mean: & 7.28 & 0.35 & 0.00 & 0.00 & 0.76 & 9.26 & 1.51 & 14.58 & 0.0 \\
\hline
\end{tabular}

Figure 9. Fracture surfaces of as-quenched samples tested at (a) $\mathrm{X} 25^{\circ} \mathrm{C}$, (b) $\mathrm{X} 200^{\circ} \mathrm{C}$, (c) $\mathrm{X} 400^{\circ} \mathrm{C}$, (d) $\mathrm{X} 700^{\circ} \mathrm{C}$ and (e) correspondig EDS of the indicated particles in samples tested at $25^{\circ} \mathrm{C}$.

quenched and tempered martensitic steel at the temperature range of 150 to $200^{\circ} \mathrm{C}$. On the other hand, ductile dimples were found in $\mathrm{AQ}$ samples (Fig. 9d) after testing at $700^{\circ} \mathrm{C}$ which led to the increase in elongation and reduction in area. Comparing the fracture surface of AR and AQ samples, it is clear that AR samples has higher density and depth of the dimples compared to the AQ samples for all testing temperatures. This gives a reasonable explanation for the fact that the AR samples has better elongation than AQ samples. Some precipitates in small holes were seen on the microfractographs of AR samples (Fig. 8c) and AQ samples
(Fig. 9a). The EDS analysis showed the presence of complex Cr-Mo-C precipitates in both AR and AQ samples.

\section{Conclusions}

DSA behaviors of $\mathrm{H} 10$ tool steel under AR and AQ conditions were investigated at a strain rate of $10^{-3} \mathrm{~s}^{-1}$ for the testing temperature of $25-700^{\circ} \mathrm{C}$. The following conclusions were drawn from the present study.

1. DSA and secondary hardening take place in the H10 tool steel under AR and AQ conditions which 
showed an increase in YS and UTS at temperatures $200^{\circ} \mathrm{C}$ and $400^{\circ} \mathrm{C}$ corresponding to DSA region. A continuous decrease in elongation was also noticed as the testing temperature increased to $400^{\circ} \mathrm{C}$ It can be concluded that above $400^{\circ} \mathrm{C}$ mechanical properties of $\mathrm{H} 10$ tool steel become so poor under AR and AQ conditions.

2. AQ samples are more susceptible to DSA than AR samples due to the presence of higher amount of $\mathrm{C}$ in martensite structure after cooling in water. As a result of this, AQ samples showed higher values in YS, UTS, but lower values in elongation (\%) compared to the AR samples for all testing temperatures of $25-700^{\circ} \mathrm{C}$.

3. The increase in the workhardening magnitude in AQ samples is quite large compared to that at room temperature. However, workhardening magnitude of AR samples showed a decrease relative to that at room temperature. This indicated that the degree of DSA in AR samples containing coarser carbides with angular shape and finer carbides with spheroid shape is much smaller than AQ samples.

4. Comparing the fracture surface of AR and AQ samples, it was observed that AR samples has higher density and depth of the dimples compared to the AQ samples for all testing temperatures. This indicates that the AR samples has better elongation than AQ samples at testing temperatures of $25-700^{\circ} \mathrm{C}$.

\section{Acknowledgments}

This work was supported by Scientific Research Projects Coordination Unit of Karabük University. Project Number: KBU-BAP-16/2-YL-072.

\section{References}

1. ASM International. Metals Handbook. $9^{\text {th }}$ ed., Volume 15. Casting. Metals Park: ASM International; 1988.

2. Davis JR, ed. ASM Speciality Handbook: Tool Materials. Materials Park: ASM International; 1995.

3. Sjöström J. Chromium martensitic hot-work tool steels - damage, performance and microstructure. [Thesis]. Karlstad: Department of Materials Engineering, Karlstad University; 2004.

4. Roberts GA, Cary RA. Tool Steels. Metals Park: American Society for Metals; 1998.

5. Arain A. Heat treatment and toughness behavior of tool steels (D2 and H13) for cutting blades. [Thesis]. Toronto: Department of Metallurgy and Materials Science, University of Toronto; 1999.

6. Medvedeva A, Bergström J, Gunnarsson S, Andersson J. High-temperature properties and microstructural stability of hot-work tool steels. Materials Science and Engineering: A. 2009;523(1-2):39-46.
7. Sachdev AK. Dynamic Strain Aging of Various Steels. Metallurgical Transaction A. 1982;13(10):1793-1797.

8. Kohandehghan AR, Sadeghi AR, Akhgar JM, Serajzadeh S. Investigation into dynamic strain aging behaviour in high carbon steel. Ironmaking and Steelmaking. 2010;37(2):155-160.

9. Bahrami A, Mousavi Anijdan SH, Golozar MA, Shamanian M, Varahram N. Effects of conventional heat treatment on wear resistance of AISI H13 tool steel. Wear. 2005;258(5-6):846-851.

10. Gladman T. The Physical Metallurgy of Microalloyed Steels. London: The Institute of Materials; 1997.

11. Gündüz S, Cochrane RC. Effect of dynamic strain ageing on mechanical properties of vanadium microalloyed steel. Materials Science and Technology. 2003;19(4):422-428.

12. Baird JD. The Inhomogeneity of Plastic Deformation. Metals Park: American Society for Metals; 1973.

13. Marschall CW, Landow MP, Wilkowski GM. ASTM STP1074 - Effect of Dynamic Strain Ageing on Fracture Resistance of Carbon Steels Operating at Light-Water Reactor Temperatures. West Conshohocken: ASTM International; 1990.

14. Honeycombe RWK, Bhadeshia HKDH. Steels, Microstructure and Properties. $2^{\text {nd }}$ ed. London: Edward Arnold; 1995.

15. Leskovšek V, Šuštaršič B, Jutriša G. The influence of austenitizing and tempering temperature on the hardness and fracture toughness of hot-worked H11 tool steel. Journal of Materials Processing Technology. 2006;178(1-3):328-334.

16. Gupta C, Chakravartty JK, Banerjee S. Microstructure, Deformation and Fracture Behavior of Cr-Mo-V Steels. International Journal of Metallurgical Engineering. 2013;2(2):142-148.

17. Keller C, Margulies MM, Guillot I. Experimental analysis of the dynamic strain ageing for a modified T91 martensitic steel. Materials Science and Engineering: A. 2012;536:273-275.

18. Mohan R, Marshall C. Cracking instabilities in a low carbon steel susceptible to dynamic strain ageing. Acta Materialia. 1998;46(6):1933-1948.

19. Leslie WC, Rickett RL. Influence of Aluminum and Silicon Deoxidation on the Strain Aging of Low Carbon Steels. Transactions of AIME. 1953;287:1021-1031.

20. Karlsen W, Ivanchenko M, Ehrnstén U, Yagodzinskyy Y, Hänninen H. Microstructural manifestation of dynamic strain ageing in AISI 316 stainless steel. Journal of Nuclear Materials. 2009;395(1-3):156-161.

21. Rodriguez P. Serrated plastic flow. Bulletin of Materials Science. 1984;6(4):653-663.

22. van Den Beukel A. Theory of the effect of dynamic strain ageing on mechanical properties. Physica Status Solidi A. 1975;30(1):197-206.

23. Gündüz S. Dynamic strain ageing effects in niobium microalloyed steel. Ironmaking and Steelmaking. 2002;29(5):341-346.

24. Lou S, Northwood DO. Elevated Temperature Mechanical Properties and Dynamic Strain Aging in Pressure Vessel Quality Steel Plate. Canadian Metallurgical Quarterly. 1992;31(3):225229.

25. Mulford RA, Kocks UF. New observations on the mechanisms of dynamic strain ageing and of jerky flow. Acta Metallurgica. 1979;27(7):1125-1134 
26. Baird JD. The effects of strain-ageing due to interstitial solutes on the mechanical properties of metal. Metallurgical Reviews. 1971;16(1):1-18.

27. Kishore R, Singh RN, Sinha TK, Kashyap BP. Effect of dynamic strain ageing on the tensile properties of modified $9 \mathrm{Cr}-1 \mathrm{Mo}$ steel. Journal of Materials Science. 1997;32(2):437-442.

28. Steel: A Handbook for Materials Research and Engineering. Düsseldorf: Verein Deutscher Eisenhüttenleute; 1992.

29. Smith WF. Structure and Properties of Engineering Alloys. New York: McGraw-Hill; 1981.
30. Mukherjee T, Sellars CM. Tensile properties of tempered chromium steels in the temperature range $0^{\circ} \mathrm{C}$ to $700^{\circ} \mathrm{C}$. Metallurgical Transactions. 1972;3(4):953-962.

31. Verma P, Sudhakar Rao G, Chellapandi P, Mahobia GS, Chattopadhyay K, Santhi Srinivas NC, et al. Dynamic strain ageing, deformation, and fracture behaviour of modified $9 \mathrm{Cr}-1 \mathrm{Mo}$ steel. Materials Science and Engineering: A. 2015;621:39-51.

32. Clough WR, Soloman JL. Neck and Split Tensile Fracture of Anisotropic Plate Steel. Journal of Basic Engineering. 1969;91(1):39-43 